\title{
Glycosylated Hemoglobin Measurement
}

National Cancer Institute

\section{Source}

National Cancer Institute. Glycosylated Hemoglobin Measurement. NCI Thesaurus. Code C64849.

A quantitative measurement of the amount of glycosylated hemog lobin present in a sample of blood. 